\title{
Analysis on the Integration Path of "One Belt And One Road" International Railway Transportation Rules
}

\author{
Guo Ruiqi ${ }^{1, *}$, Zhang Shuyin ${ }^{1}$, Zhang Zhuangzhi ${ }^{1}$,Wang Kunmin ${ }^{1}$, Cai Yinghui ${ }^{1}$, Yu Changjiang ${ }^{2}$ and Wang Zirui ${ }^{1}$ \\ ${ }^{1}$ Logistics Department, Shandong Jiaotong University, Jinan Shandong Province, 250357, China \\ ${ }^{2}$ Traffic Equipment and Control Engineering, Shandong Jiaotong University, Jinan Shandong Province, 250357, China
}

\begin{abstract}
With the rapid growth of Sino-European international trade and the ongoing development of "One Belt And One Road", it can be predicted that the status of railway transportation in the international logistics system will be greatly enhanced, which urges us to further study the rules of international railway freight transportation. At present, the pattern of the rules system of international freight transport by railway is the two conventions of the international cargo association and the international cargo contract. In addition, the existing rules system of freight transport by railway in China also has some problems such as being too administrative, which needs to be reformed urgently. By comparing the contents of the two conventions of international railway freight transport and listing the possible conflicts in the substantive laws of various countries involved in the conventions, this paper designs a set of dispute settlement mechanism for "One Belt And One Road" railway transport, and puts forward some suggestions on the integration of the rules of "One Belt And One Road" international railway freight transport.
\end{abstract}

\section{Introduction}

As a country with the most complete high-speed railway system, the fastest development, the longest operating mileage and the strongest integration capability in the world, China has built high-speed railway into a mass transportation tool with practical experience. Great practices give birth to great technologies, and it has become an established fact that China's high-speed railway "goes global".

As a traditional land trading power, China has been connecting its neighbors mainly through the famous "ancient Silk Road" since historical times. The Silk Road was an important trade and transportation route across the Eurasian continent in history. In 2013, China put forward the strategic concept of "One Belt And One Road", which is a new trade road connecting Asia with Europe and the world, and is known as "a new concept of Chinese diplomacy" in the international community. The connectivity of infrastructure is the priority area of "One Belt And One Road" construction, and the starting point of Chinese railway equipment to the world is the main area covered by "One Belt And One Road". High-speed railway is the core product of China's "One Belt And One Road" export. It is an important breakthrough to change China's export industrial structure and realize the transformation and upgrading of domestic economy. At the same time, it can also meet the booming demand of high-speed railway construction in the world. When we turn the sharing of high-speed railway achievements into a diplomatic tool, it can become a "new magic weapon" to build a new image of China's modernization and show the world that China has upgraded from "made in China" to "made in China intelligently".

\section{Analysis of present situation of domestic railway transportation}

With the continuous development of China's economy, China's railway construction level and railway transport capacity has been greatly improved, and the corresponding equipment is also very modern. However, the railway operation in China is not very unsatisfactory, and there are still many problems, as shown in Figure 1.re are still many problems, as shown in Fig 1.

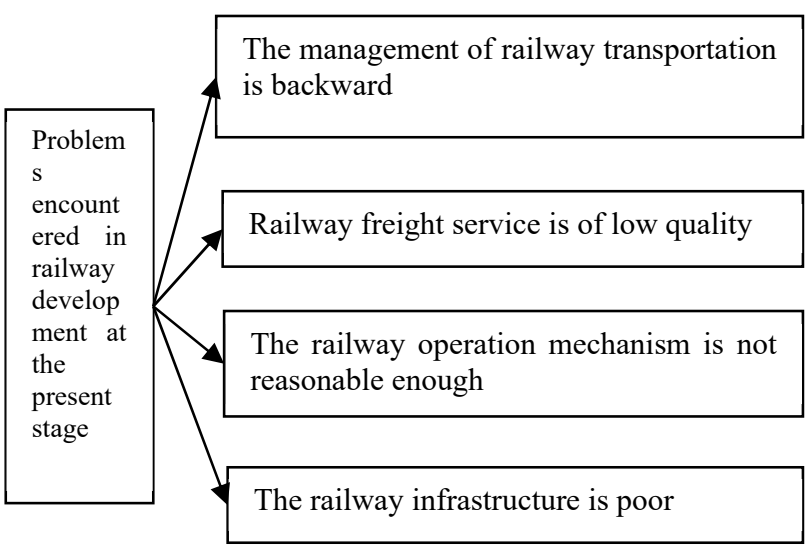

Fig. 1. Problems encountered in railway development at the present stage 


\subsection{Analysis of the problem of backward railway transportation management mode in China}

At present, the informatization of railway transportation in our country still has no great effect, so that customers can not timely understand the relevant transportation information. Secondly, the railway marketing management mode is not optimistic, China's railway transport prices are the same throughout the year, there is no peak season points, which leads to the marketing role has not been very good play. In addition, the development of railway transportation will be inhibited due to the low enthusiasm of railway employees, low service quality, poor customer service attitude, and customers turning to other means of transportation.

\subsection{Analysis of the low quality of railway freight transport service in China}

As China's railway transportation has always been the government's administrative monopoly industry, it does not have a lot of enthusiasm to carry out the related development and service of customers. For example, the poor concept of time in railway management always leads to unpunctuality, which often happens but has not been improved accordingly, resulting in low customer service satisfaction and ultimately loss of customers. The randomness of railway-related services and the complexity of freight handling procedures and other problems lead to long delivery times. Under such a management mechanism, there is no time to deal with special situations such as natural disasters.

\subsection{Analysis of the unreasonable railway operation mechanism in China}

The railway transportation enterprises in China are basically owned by the government, which can not make corresponding and flexible adjustment according to the current social development mode due to the separation of government and enterprise, and the management of railway transportation enterprises lacks the ability to cope with competition. The cost of government-run enterprises is also very high, and this problem has become more prominent in recent years. The reason is that the government monopoly in the railway transportation industry leads to the unreasonable railway operation mechanism, low productivity, and the development of the industry has also encountered obstacles.

\subsection{Analysis of the problem of backward railway infrastructure in China}

With the continuous development of China's economy, the demand for railway loading capacity and transportation capacity is getting higher and higher, especially the lack of large-scale and professional railway hubs. At present, many railway stations in China are faced with the problem of upgrading and transformation. However, many old stations are small in scale but located in the city, and the obsolete facilities and equipment in them make it impossible to expand, which inhibits the improvement and construction of railway. In addition, the railway can not realize the door-to-door service characteristics, but also depends on the cooperation of other means of transportation, which ultimately leads to the decrease of commodity profits and the reduction of competitive advantage.

\section{3 "One Belt And One Road" international railway cargo transport status analysis}

As the initiator of "One Belt And One Road", there are some problems in the legislation and judicature of railway transportation in China which need to be improved. The international community also has a foreboding about the integration process of railway transport rules. However, many attempts can only be made to unify part of the system. "One Belt And One Road" crosses the Eurasian continent, and there are different policies and regulations in the countries along the route, such as the inconsistency of waybill, the customs clearance system and the classification of the types and grades of the goods. These problems also hinder the improvement of customs clearance efficiency in reality, and reduce the efficiency of railway freight transport.

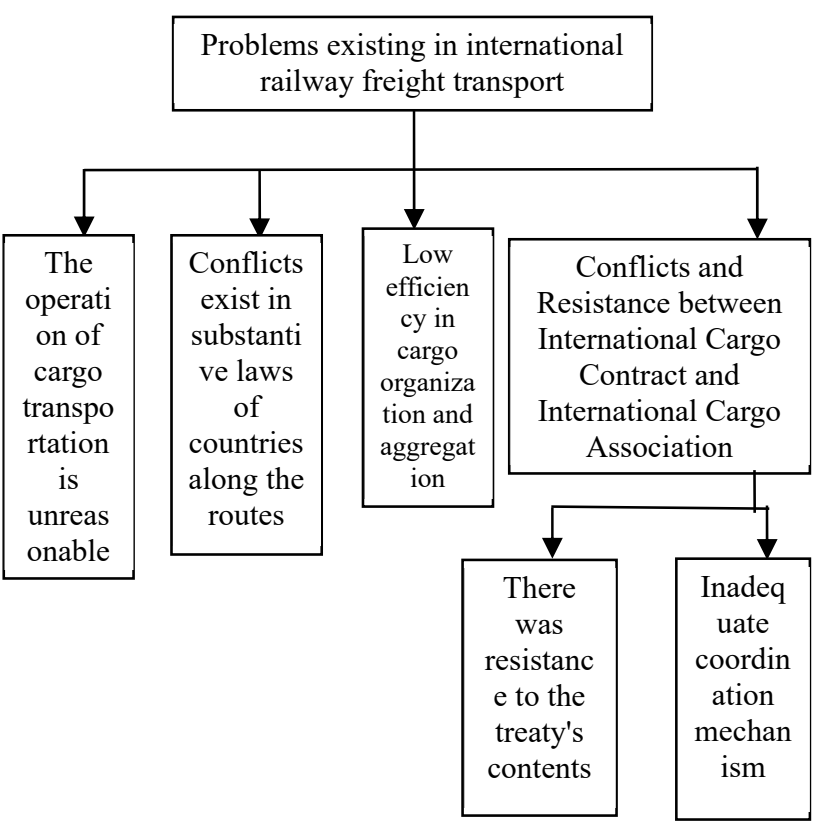

Fig. 2. The problems existing in "One Belt And One Road" international railway cargo transportation

\subsection{Analysis of unreasonable cargo transportation operation}

In terms of the current development of "One Belt And One Road", the number of trains running on China-Europe and China-Central Asia freight trains has increased significantly compared with the past. However, due to the limitation of the number of opening cities and the influence of unstable factors of international goods supply, 
the opening number of China-Europe freight trains is also relatively limited, which also causes the phenomenon of relatively single international cargo transportation. And this phenomenon has a certain gap compared with the actual demand of goods.

\subsection{Analysis of conflicts in substantive laws of countries along the Belt and Road}

On the management mode of railway transportation, although the overall management mode of railway transportation is free, but there are completely controlled by the state monopoly of railway transportation, for example, according to the current bilateral agreement in the international trade transportation both sides uphold the principle of mutual convenience to allow the other vehicle routes for licensed can directly by the agreement to the other party hinterland, Eliminating inconvenient procedures such as changing cars would reduce transport costs for both sides, but Kazakhstan actually requires goods to be shipped at its border ports to be transferred to their destination in local vehicles. China's railway transportation to Russia often hit a wall because of the changeable Russian policy.

\subsection{Analysis of the problem of low supply organization and agglomeration effect}

From the operation situation of the domestic and foreign cities through which "One Belt And One Road" passes, the source organization of international goods concentrates in a part of the cities because the Sino-Europe and Central Asia freight trains are affected by various factors such as departure stations and operation routes at the beginning of their operation.

\subsection{Analysis of the conflict and conflict between the International Cargo Contract and the International Cargo Association}

\subsubsection{There is a conflict in the content of the treaty}

As two different systems of rules, they are comparable in terms of treaty content and quite different. From the perspective of the provisions, the most obvious differences lie in the detailed degree of the requirements of transport documents, the rights and obligations of shippers, consignees and carriers, and the different provisions on the jurisdiction and limitation of action of the disputes in the international railway transport of goods between the International Freight Association and the International Cargo Contract.

\subsubsection{Coordination mechanism and its deficiencies}

Railway transportation is the key construction object of "One Belt And One Road" initiative. However, under the current system of international railway cargo transportation rules, the International Cargo Contract and the International Cargo Association both have some deficiencies. From the perspective of coverage, neither of the two conventions can independently cover the countries along the "One Belt And One Road" initiative. Seen from the contents of the two conventions, except that the executing agencies of the two conventions have cooperated to coordinate the uniform transport documents, the executing agencies of the two conventions have no intention to coordinate and unify the many differences in the provisions of the two conventions.

\section{Analysis on the integration of "One Belt And One Road" international railway transport rules}

The "One Belt And One Road" initiative spans a wide range of national cities, across a number of legal systems, and also across the International Cargo Association (IFA) and International Cargo Contract (ICA) in terms of the rules of international railway freight transport. In today's international law itself is fragmented, neither International Cargo Association nor International Cargo Contract can fully meet the needs of international railway transportation. So advocate the area along the "international rules of railway transportation integration is also should be, it is necessary to break along the gap between countries, build political mutual trust, to promote" area "under the initiative of the international carriage of goods by rail, the construction of the area along the" international rules of railway transportation integration, basically has the following several principles, figure as shown in figure 3.

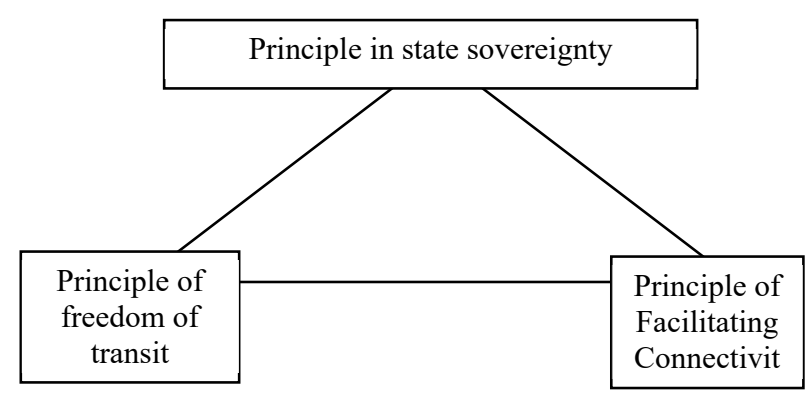

Fig. 3. Basic principles of the integration of international railway transport rules

\subsection{Analysis of concrete measures for the integration of "One Belt And One Road" railway transport rules}

Table 1 Analysis of specific measures for integration of transport rules

\begin{tabular}{|l|l|}
\hline \multicolumn{1}{|c|}{ concrete measure } & \multicolumn{1}{|c|}{ Measures analysis } \\
\hline $\begin{array}{l}\text { 1. Formulation of "One Belt And One Road" } \\
\text { Convention on the Transport of Goods by } \\
\text { Railway }\end{array}$ & $\begin{array}{l}\text { Neither International Cargo Association nor International Cargo Contract can } \\
\text { fully meet the needs of international railway transportation. The two conventions } \\
\text { show different international railway intermodal regulations, which are full of }\end{array}$ \\
\hline
\end{tabular}




\begin{tabular}{|c|c|}
\hline & their own regional characteristics of intermodal regulations. \\
\hline $\begin{array}{l}\text { 2. Establish "One Belt And One Road" } \\
\text { intergovernmental cooperation organization } \\
\text { for railway transportation }\end{array}$ & $\begin{array}{l}\text { At present, the railway logistics information construction of each country in } \\
\text { Eurasia continent is relatively sound, but there is a lack of information sharing } \\
\text { at the level of international railway logistics. From the experience of the } \\
\text { construction of land Bridges in North America, information exchange in logistics } \\
\text { and other aspects is an essential factor for the successful development of land } \\
\text { Bridges. Set at the same time, draw lessons from the international cargo about } \\
\text { the central bureau as its actuator, under the "area" initiative formed unified rules } \\
\text { of railway transportation convention also should set an actuator, the agency also } \\
\text { as "area" intergovernmental cooperation organization of railway transportation, } \\
\text { the main negative expensive railway transportation logistics information } \\
\text { communication, national railway transport policy document sharing. }\end{array}$ \\
\hline $\begin{array}{l}\text { 3.Promote bilateral cooperation mechanisms } \\
\text { for the transport of railway goods along the } \\
\text { Belt and Road }\end{array}$ & $\begin{array}{l}\text { Railway transport regulation involves many domestic mandatory provisions, in } \\
\text { order to fully respect the judicial sovereignty of each country, also in order to } \\
\text { avoid when making new convention caused by excessive pay attention to the } \\
\text { unity of the convention, due to a lack of flexibility and make the countries } \\
\text { concluded the convention will cut, is not suitable for the treatment of the } \\
\text { convention sovereign state of the domestic issues of the mandatory law has a } \\
\text { regulation. } \\
\text { However, the difficulties in trying to unify the railway transport of many } \\
\text { countries do not directly deny the possibility of consultation and unification } \\
\text { among a small number of countries on the relevant matters. }\end{array}$ \\
\hline
\end{tabular}

"One Belt And One Road" can not only be regarded as a simple strategic alliance, but represents China's prediction and guidance of the future development trend of the Eurasian continent and even the world. China should always be in the leadership of the One Belt And One Road initiative and truly make the One Belt And One Road initiative the compass of economic global development.

\section{Conclusion}

The development of the world today is the development of the community of human destiny and build process, and the existing rules of international carriage of goods by rail system was not able to make most of the national identity and share one rule, thus, a broken and incomplete system of rules will be eliminated by the tide of history, the international rules of railway goods transportation integration is a necessary demand of reality.

At present, the Belt and Road Initiative will extend international rail freight transport to a wider inland hinterland, and the existing rules of international rail freight transport may have problems affecting its efficiency. With the help of "One Belt And One Road" which is widely accepted as the basis to promote the integration process of international railway freight transport rules, is also conducive to the development and reform of China's domestic railway freight transport rules system, will become a win-win initiative and measures between China and the world.

\section{References}

1. Xu Xijun, When China-EU Freight Trains "Walk Independent", China Communications News 2018

2. Xu Xijun, National "One Belt And One Road" Strategy: Opportunities and Challenges of Logistics
Industry on the Eurasian Continental Bridge, Academic Journal of Huaihai Institute of Technology, 2020

3. Zhao Deqiang, A Brief Analysis of the Challenges and Opportunities of Railway Transportation Industry, Transport Department of Lanzhou Railway Bureau, 2015.

4. Li Hong, Research on the Development Path of Railway Transportation in Transportation Integration, Science and Technology and Innovation 2017.

5. Wang Peihong, He Guoguang, The development direction of integrated transportation, integrated transportation 2019

6. Jia Guangzhi, The legal framework system and development inspiration of EU railway reform, integrated transport 2018. 